\title{
FAKTOR - FAKTOR YANG MEMPENGARUHI KEJADIAN DIARE PADA BALITA : SEBUAH REVIEW
}

\author{
Yura Witsqa Firmansyah ${ }^{1)}$, Muhammad Fadli Ramadhansyah ${ }^{1)}$, \\ Mirza Fathan Fuadi ${ }^{1)}$, Nurjazuli Nurjazuli ${ }^{1)}$ \\ ${ }^{1)}$ FKM Universitas Diponegoro
}

\begin{abstract}
Abstrak
Diare masih menjadi masalah kesehatan di dunia termasuk Indonesia. Diare dapat terjadi pada semua kelompok umur, terutama balita yang menjadi kelompok rentan dengan prevalensi sebesar $23,4 \%$. Terdapat banyak faktor yang mempengaruhi kejadian diare seperti tingkat pengetahuan ibu, perilaku hidup bersih dan sehat, dan kondisi lingkungan. Penelitian ini bertujuan untuk memberikan informasi faktor-faktor yang terbukti sebagai risiko kejadian diare pada balita berdasarkan kajian review. Metode dalam penelitian ini adalah deskriptif dengan pendekatan scoping review dengan penelusuran jurnal penelitian melalui database sinta. Adapun kriteria jurnal penelitian yang digunakan adalah terindeks pada sinta 2, 3, dan 4, memiliki sitasi lebih dari 200, waktu publikasi 10 tahun terakhir, dan memiliki variabel yang terbukti sebagai faktor risiko kejadian diare berbasis review adalah tingkat pengetahuan ibu, riwayat pemberian ASI, kondisi sarana air bersih, sumber air minum, kebiasaan mencuci tangan setelah BAB pada ibu balita, mencuci tangan sebelum memberikan makan balita, mencuci tangan sebelum masak, dan peralatan makan balita, serta kondisi jamban. Kesimpulan dalam penelitian ini adalah terdapat beberapa faktor yang terbukti berisiko terhadap kejadian diare seperti faktor pengetahuan ibu, perilaku hidup bersih dan sehat, serta faktor lingkungan.kejadian diare pada balita. Hasil penelitian ini didapatkan bahwa variabel yang terbukti sebagai faktor risiko.
\end{abstract}

Kata kunci: Diare ; Balita ; Review

\begin{abstract}
Diarrhea is still a health problem in the world, including Indonesia. Diarrhea can occur in all age groups, especially under five who are the vulnerable group with a prevalence of $23.4 \%$. There are many factors that influence the incidence of diarrhea, such as the level of maternal knowledge, hygiene and healthy living habits, and environmental conditions. This study aims to provide information on proven factors as a risk of diarrhea incidence in children under five based on a review study. The method in this research is descriptive with a scoping review approach by tracing research journals through the Sinta database. The criteria for research journals used are indexed in sinta 2, 3, and 4, have more than 200 citations, the publication time of the last 10 years, and have proven variables as risk factors for diarrhea incidence in children under five. The results of the study found that the variables that proved to be risk factors for the incidence of diarrhea based on reviews were the level of mother's knowledge, history of offering breast milk, the condition of clean water facilities, drinking water sources, hand washing equipment after defecating in mothers of toddlers, washing hands before feeding toddlers, washing hands. hand before cooking, eating utensils for toddlers, and the condition of the latrine. The conclusion in this study is that there are several factors that are proven to be at risk for the incidence of diarrhea, such as maternal knowledge, clean and healthy living habits, and environmental factors.
\end{abstract}

Keywords: diarrhea ; toddlers ; review 


\section{Pendahuluan}

Diare masih menjadi masalah kesehatan di dunia termasuk Indonesia. Penyakit diare dapat muncul dikarenakan berbagai macam penyebab seperti terinfeksi kuman seperti Shigella sp. Salmonella, Campylobacter dan Escherichia coli., Intoleransi terhadap makanan seperti laktosa dan fruktosa, alergi makanan, efek samping dari obatobatan, daerah geografis, tingkat sanitasi dan kebersihan (Kemenkes, 2005).

Kejadian diare di Indonesia merupakan penyebab kematian nomor dua pada anak usia dibawah 5 tahun. Angka Kematian Balita (AKBA) merupakan salah satu indikator kesehatan yang dinilai paling peka dan telah disepakati secara nasional sebagai ukuran derajat kesehatan suatu wilayah. Secara nasional, target SDGs untuk menurunkan Angka Kematian Balita di Indonesia dalam kurun waktu 2015-2030 menjadi 25 per 1000 kelahiran hidup. Pada tahun 2016, AKBA di Indonesia tercatat 26 per 1000 kelahiran hidup (BPPN, 2020).

Diare lebih sering terjadi pada anak usia 2 tahun karena usus anak-anak sangat peka terutama pada tahun-tahun pertama dan kedua. Berdasarkan karakteristik penduduk pada kelompok umur, data insiden diare dan periode prevalensi diare yang paling tinggi adalah kelompok umur $<1$ tahun dengan insiden $7 \%$ periode prevalensi $11,2 \%$ dan kelompok umur 1-4 tahun dengan insiden 6,7\% periode prevalensi $12,2 \%$. Kurang lebih $80 \%$ kematian terjadi pada balita kurang dari 1 tahun dan risiko menurun dengan bertambahnya usia (Hernayati, 2019).

Kejadian Luar Biasa (KLB) diare yang terjadi terjadi pada tahun 2017 tercatat sebanyak 21 kali yang tersebar di 12 provinsi dan 17 kabupaten/kota dengan jumlah penderita 1725 orang dan kematian sebanyak 34 orang (CFR 1,97\%) (Kemenkes, 2018). Jawa Timur menjadi provinsi yang mempunyai kasus diare tertinggi ke-2 sebanyak 151.878 dengan prevalensi 7,6\%, sedangkan Surabaya menangani sejumlah 78.463 kasus hampir $50 \%$ dari total kasus diare di Jawa Timur (Kemenkes, 2019)

Data dari Kemenkes RI (2019) dalam Riset Kesehatan Dasar (Riskedas) untuk tahun 2018, kelompok umur 1-4 tahun $(12,8 \%)$ dan jenis kelamin perempuan $(8,3 \%)$ adalah kelompok yang paling banyak penderitanya. Keadaan sosio-ekonomi juga menjadi faktor yang berhubungan dengan kejadian diare. Semakin baik keadaan sosioekonomi suatu keluarga, semakin berkurangnya insiden terjadinya diare (Oliviera, 2017).

Penyakit ini merupakan penyakit yang menular dan ditandai dengan gejala-gejala seperti perubahan bentuk dan konsistensi tinja menjadi lembek hingga mencari dan bertam bahnya frekuensi buang air besar lebih dari pada biasanya disertai dengan muntah-muntah, sehingga menyebabkan penderita mengalami kekurangan cairan dalam tubuh atau dehidrasi yang pada akhirnya apabila tidak mendapatkan pertolongan segera dapat menyebabkan terjadinya keparahan hingga kematian.

Hingga saat ini, diare masih merupakan salah satu penyebab uama kesakitan dan kematian hampir di seluruh daerah geografis di dunia dan dapat menyerang segala kelompok usia, tetapi penyakit berat dengan kematian yang tinggi cenderung terjadi pada bayi dan anak balita (UNICEF). Menurut data WHO diare adalah penyebab nomor satu kematian balita di dunia. Di Indonesia diare adalah penyebab kematian balita nomor dua setelah Infeksi Saluran Pernapasan Atas (ISPA). UNICEF memperkirakan bahwa setiap 30 detik ada anak yang meninggal karena diare. Di Indonesia setiap tahun 100.000 anak meninggal dunia karena diare. (Depkes RI, 2005).

Ada beberapa faktor yang berkaitan dengan kejadian diare, yaitu keterbatasan penyediaan air bersih, air tercemar oleh tinja, kekurangan sarana kebersihan, pembuangan tinja yang tidak higienis, kebersihan perseorangan dan lingkungan yang buruk, serta penyiapan dan penyimpanan makanan yang tidak semestinya (Sander, 2005). Faktor lingkungan yang paling dominan yaitu sarana penyediaan air bersih dan pembuangan tinja, kedua faktor ini akan berinteraksi bersama dengan perilaku manusia. Apabila faktor lingkungan tidak sehat karena terkena kuman diare serta berakumulasi dengan perilaku manusia yang tidak sehat pula, maka penularan diare dengan mudah dapat terjadi (Depkes, 2005).

Faktor lainnya adalah makanan yang tidak higienis, tempat penyimpanan makanan dingin yang kurang, kontak makanan dengan lalat, dan mengonsumsi air minum yang tercemar (Lever, 2009). Salah satu faktor risiko yang menjadi penyebab diare pada balita adalah Perilaku Hidup Bersih dan Sehat sehingga upaya yang dapat dilakukan untuk mengurangi kejadian diare pada balita dapat menerapkan Perilaku Hidup Bersih dan Sehat (PHBS). PHBS dapat dipengaruhi oleh beberapa faktor seperti pengetahuan yang sangat berkaitan dalam upaya memperbaiki perilaku. Meningkatnya pengetahuan akan memberikan hasil yang cukup berarti untuk memperbaiki perilaku. Pengetahuan merupakan inti yang sangat penting bagi terbentuknya perilaku, oleh karena itu orang tua perlu memiliki pengetahuan yang cukup agar dapat menghindari hal-hal yang dapat menimbulkan penyakit diare (Kemenkes, 2011)

Uraian permasalahan diatas, maka peneliti tertarik untuk memberikan gambaran faktor-faktor yang menjadi risiko terhadap kejadian diare pada balita melalui literature review. 


\section{Bahan dan Metode}

Penelitian ini merupakan deskriptif dengan pendekatan scoping review. Sampel pada penelitian ini adalah jurnal penelitian melalui penelusuran database sinta dari Kementerian Riset dan Teknologi / Badan Riset.

\section{Hasil dan Pembahasan}

\section{a. Matrik Sintesis Karakteristik Penerbitan Jurnal}

Tabel 1. Karakteristik Penerbit Jurnal

\begin{tabular}{|c|c|c|c|c|c|}
\hline Sumber & $\begin{array}{l}\text { Nama } \\
\text { Penulis, } \\
\text { Tahun } \\
\text { Terbit } \\
\end{array}$ & Penerbit & $\begin{array}{l}\text { Index } \\
\text { Sinta }\end{array}$ & $\begin{array}{l}\text { Impact } \\
\text { Factor }\end{array}$ & $\begin{array}{l}\text { Citat } \\
\text { ions }\end{array}$ \\
\hline $\begin{array}{c}\text { Sumber } \\
1\end{array}$ & $\begin{array}{l}\text { Yulianto } \\
\text { Wijaya, } \\
2012 .\end{array}$ & $\begin{array}{l}\text { Unnes } \\
\text { Journal of } \\
\text { Public } \\
\text { Health. }\end{array}$ & 2 & 8.64 & 3250 \\
\hline $\begin{array}{c}\text { Sumber } \\
2\end{array}$ & $\begin{array}{l}\text { Lailatul } \\
\text { Mafazah } \\
, 2013 .\end{array}$ & $\begin{array}{l}\text { Jurnal } \\
\text { Kesehatan } \\
\text { Masyarakat } \\
\text {, Unnes. }\end{array}$ & 2 & 8.64 & 3250 \\
\hline $\begin{array}{c}\text { Sumber } \\
3\end{array}$ & $\begin{array}{l}\text { Laila } \\
\text { Kamilla, } \\
\text { Suharton } \\
\text { o, Nur } \\
\text { Endah } \\
\text { W., } \\
2018 .\end{array}$ & $\begin{array}{l}\text { Jurnal } \\
\text { Kesehatan } \\
\text { Lingkungan } \\
\text { Indonesia, } \\
\text { Universitas } \\
\text { Diponegoro } \\
\text {. }\end{array}$ & 2 & 2.37 & 1153 \\
\hline $\begin{array}{c}\text { Sumber } \\
4\end{array}$ & $\begin{array}{l}\text { Hannif, } \\
\text { Nenny } \\
\text { Sri } \\
\text { Mulyani, } \\
\text { Susy } \\
\text { Kuscitha } \\
\text { wati, } \\
2011 .\end{array}$ & $\begin{array}{l}\text { Berita } \\
\text { Kedokteran } \\
\text { Masyarakat } \\
\text { Universitas } \\
\text { Gadjah } \\
\text { Mada. }\end{array}$ & 3 & 2.45 & 1692 \\
\hline $\begin{array}{c}\text { Sumber } \\
5\end{array}$ & $\begin{array}{l}\text { Susi } \\
\text { Hartati, } \\
\text { Nurazila } \\
, 2018 .\end{array}$ & $\begin{array}{l}\text { Jurnal } \\
\text { Endurance : } \\
\text { Kajial } \\
\text { Ilmiah } \\
\text { Problema } \\
\text { Kesehatan, } \\
\text { LLDIKTI } \\
\text { Wilayah X. }\end{array}$ & 3 & 2.12 & 1051 \\
\hline $\begin{array}{l}\text { Sumber } \\
6\end{array}$ & $\begin{array}{l}\text { Herry } \\
\text { Tomy } \\
\text { Ferlland } \\
\text { o, } \\
\text { Supriyo } \\
\text { no } \\
\text { Aswafi, } \\
2015\end{array}$ & $\begin{array}{l}\text { Visikes : } \\
\text { Jurnal } \\
\text { Kesehatan } \\
\text { Masyarakat } \\
\text { Universitas } \\
\text { Dian } \\
\text { Nuswantor } \\
\text { o. }\end{array}$ & 4 & - & 237 \\
\hline
\end{tabular}

Tabel 1 menjelaskan karakteristik penerbit jurnal penelitian yang digunakan sebagai sampel dan bahan dalam pembuatan kajian review. Terdapat 6 jurnal penelitian yang memenuhi kriteria penetapan sebagai sampel jurnal penelitian.
Tabel 2. Identifikasi variabel jurnal

\begin{tabular}{cll}
\hline Sumber & Variabel yang Diteliti & $\begin{array}{c}\text { Variabel yang Menjadi } \\
\text { Faktor Risiko }\end{array}$ \\
\hline 1 & Tingkat pengetahuan, & Tingkat pengetahuan ibu \\
jenis pekerjaan ibu, umur & (OR: 16), riwayat pem- \\
ibu, riwayat pemberian & berian ASI (OR: 28,5), \\
& ASI, kebiasaan ibu men- & kebiasaan ibu mencuci \\
& cuci tangan, jenis SAB, & tangan (OR: 16), jenis \\
& jarak SAB ke TPS, jenis & jamban (OR: 9,33), \\
jamban, jenis lantai & kepadatan lalat (OR: \\
& rumah, kepadatan lalat. & $9,33)$.
\end{tabular}

2 Karakteristik balita, Ketersediaan sarana air karakteristik responden, bersih (p: 0,001) variabel personal ketersediaan sarana pemhygiene ibu, variabel buangan tinja (p: 0,002), ketersediaan sarana pe- ketersediaan sarana nyediaan air bersih, tempat pembuangan ketersediaan sarana pem- sampah (p: 0,001), buangan tinja, keter- ketersediaan sarana pemsediaan sarana tempat buangan air limbah (p: pembuangan sampah, 0,001) dan personal dan ketersediaan sarana hygiene ibu (p: 0,001).

pembuangan air limbah (SPAL).

3 Praktik personal hygiene: praktik mencuci tangan dengan sabun sebelum makan, praktik mencuci tangan menggunakan sabun setelah $\mathrm{BAB}$, praktik mengelola makanan yang baik.

Kondisi sanitasi lingkungan rumah: kepemilikan jamban sehat, kondis SPAL, kualitas bakteriologis air bersih, kondisi tempat sampah.

Risiko sarana air bersih, sarana pembuangan tinja, total coliform dan E. Coli sampel air bersih, higiene perorangan dan perilaku merebus air minum. Variabel terikat adalah kejadian diare akut pada balita.

5 Pendidikan, pengetahuan, perilaku cuci tangan

Pendidikan (p: 0,000), pengetahuan (p: 0,000), dan perilaku cuci tangan (p: 0,000),

6 Personal hygiene, kondisi lingkungan, penyediaan air bersih, dan ketersediaan jamban

Personal hygiene (p: 0,000), kondisi lingkungan (p: 0,000) dan ketersediaan air bersih (p: 0,023) 
b. Tingkat Pengetahuan Ibu dengan Kejadian Diare

Tingkat pengetahuan ibu merupakan peranan yang terpenting terhadap kejadian diare. Seperti pengetahuan perilaku hidup bersih dan sehat, pengetahuan dalam mencegah risiko kejadian diare (Yulianto Wijaya, 2012). Tingkat pengetahuan kaitannya erat dengan tingkat pendidikan, pada umumnya tingkat pendidikan rendah akan berbanding lurus dengan tingkat pengetahuan seseorang.

\section{c. Riwayat Pemberian ASI dengan Kejadian Diare}

Pemberian ASI dalam sumber pertama (Yulianto Wijaya, 2012) menjadi faktor risiko terhadap kejadian diare. Beberapa alasan yang mendasari seperti pada saat kelahiran awal ASI belum keluar, paradigma ibu tentang penambahan makanan sebelum waktunya, serta anggapan susu formula lebih baik daripada ASI.

Penelitian lain yang sejalan adalah (Winda Wijayanti, 2010) balita yang tidak mendapatkan ASI eksklusif akan lebih besar mengalami diare dibandingkan dengan balita yang mendapatkan ASI eksklusif. ASI merupakan sumber antibiotik alami dalam tubuh balita sehingga bisa menurunkan morbiditas berbagai penyakit, terutama diare (Depkes RI, 2011).

\section{d. Kondisi Sarana Air Bersih dengan Kejadian Diare}

Peraturan Menteri Kesehatan Republik Indonesia Nomor 416/MENKES/PER/IX/1990 menyatakan bahwa air bersih merupakan air yang digunakan masyarakat guna memenuhi kebutuhan sehari-hari dengan memperhatikan syarat air bersih yaitu dari segi fisik seperti warna, bau, rasa, dan kekeruhan, segi bakteriologis meliputi kuman-kuman parasitik, kumankuman pathogen dan bakteri E-Coli, sedangkan dari segi kimia sendiri air bersih tidak boleh mengandung zat-zat bahaya yang dapat memberikan dampak terhadap gangguan kesehatan pada masyarakat, tidak mengandung zat beracun dan tidak mengandung zat yang kadarnya melebihi baku mutu yang telah ditentukan. Untuk memutus rantai pada penularan penyakit diare, seharusnya masyarakat menyediakan air bersih yang memenuhi syarat kesehatan termasuk pada letak sumber air bersih guna mencegah terjadinya pencemaran berkelanjutan.

\section{e. Sumber Air Minum dengan Kejadian Diare}

Kebutuhan manusia akan air sangat kompleks, antara lain untuk minum, masak, mandi, mencuci, dan sebagainya. Berdasarkan teori yang dikemukakan oleh Chandra dalam bukunya Pengantar Kesehatan Lingkungan, bahwa ditinjau dari sudut ilmu kesehatan masyarakat, penyediaan sumber air bersih harus dapat memenuhi kebutuhan masyarakat karena persediaan air bersih yang terbatas memudahkan timbulnya penyakit di masyarakat (WHO, 2009).
Sumber air minum mempunyai peranan dalam penyebaran beberapa penyakit menular. Sarana penyediaan air minum merupakan salah satu sarana sanitasi yang berkaitan dengan kejadian diare. Sebagian kuman infeksius penyebab diare ditularkan melalui jalur fecal oral. Kuman dapat ditularkan dengan masuk ke dalam mulut, cairan atau benda yang tercemar dengan tinja.

\section{f. Kebiasaan Mencuci Tangan Setelah BAB Pada Ibu Balita dengan Kejadian Diare}

Menurut teori yang dikemukakan oleh Tietjen pada tahun 2004, cuci tangan adalah proses membuang kotoran dan debu secara mekanis dari kulit kedua belah tangan dengan memakai sabun dan air. Kesehatan dan kebersihan tangan dapat mengurangi jumlah mikrooganisme penyebab penyakit pada kedua tangan dan lengan, serta meminimalisasi kontaminasi silang. Tujuan cuci tangan adalah menghilangkan kotoran mekanis dari permukaan kulit dan mengurangi jumlah mikrooganisme sementara (Tietjen L,2004).

Kebiasaan mencuci tangan setelah buang air besar dengan benar sangat penting dan dapat meminimalisir risiko penularan maupun terjadinya diare. Kebiasaan yang berhubungan dengan kebersihan merupakan bagian penting dalam penularan diare, sehingga dengan mencuci tangan dengan benar dan tepat dapat memutus rantai penularan penyakit diare.

\section{g. Mencuci Tangan Sebelum Memasak dengan Kejadian Diare}

Kuman penyebab diare bisa terdapat dimanapun pada saat kita melakukan aktivitas sehari-hari dan kuman tersebut dapat menempel pada tangan. Oleh karenanya sebaiknya mencuci tangan dilakukan sebelum menjamah makanan. Hal ini sesuai dengan pernyataan yang menyatakan bahwa orang menjadi sakit disebabkan karena mengkonsumsi makanan atau minuman yang tercemar (Sugianto, 1983).

Kuman penyebab penyakit diare bisa terdapat dimanapun apabila kita sering melakukan aktivitas seharihari, maka kuman dapat menempel pada tangan. Oleh sebab itu seharusnya tangan dicuci dahulu sebelum menjamah makanan. Karena tangan yang tidak dicuci bersih sebelum dan sesudah menjamah makanan merupakan salah satu media penularan infeksi saluran pencernan.

\section{h. Mencuci Tangan Sebelum Memberi Makan Balita dengan Kejadian Diare}

Kebiasaan mencuci tangan sebelum memberi makan balita berpengaruh terhadap terjadinya diare pada balita. Hal ini disebabkan karena balita sangat rentan terhadap mikrooganisme dan berbagai agen infeksius. Segala aktivitas balita dibantu oleh orang tua khususnya ibu, sehingga mencuci tangan sangat diperlukan oleh ibu sebelum dan sesudah kontak dengan balita. Tujuannya untuk menurunkan risiko teradinya diare pada balita. Mencuci tangan yang baik dan benar dapat menurunkan angka kejadian diare sebesar 47\% (Ngaw S, 2011). 
Kebiasaan mencuci tangan sebelum memberi makan balita merupakan faktor risiko teradinya diare pada balita karena tangan yang tidak dibersihkan dengan benar dapat menjadi media masuknya kuman ke dalam tubuh melalui kontak langsung dengan mulut maupun dengan makanan dan minuman.

\section{i. Mencuci Peralatan Makan Balita dengan Kejadian Diare}

Setiap perlatan makan harus dicuci dengan air yang mengalir dan menggunakan detergen atau bila menggunakan ember harus sering diganti airnya, peralatan yang sudah bersih disimpan ditempat yang tertutup dan tidak memungkinkan terjadinya pencemaran, demikian pula lap yang digunakan harus sering diganti agar tidak terjadi pencemaran ulang lap yang kotor pada peralatan yang sudah bersih. Peralatan makan yang tidak dicuci dengan benar dan bersih masih dimungkinkan terdapat kuman yang dapat terkontaminasi pada makanan. Selain itu peralatan makan yang tidak disimpan pada tempat yang tertutup dapat meningkatkan risiko kontaminasi debu dan lalat terhadap perlatan makan (Kemenkes RI, 2013)

\section{j. Kondisi Jamban dengan Kejadian Diare}

Pemanfaatan jamban keluarga berguna untuk menjaga lingkungan agar tetap dalam keadaan bersih, sehat dan tidak berbau. Penggunaan jamban juga berguna untuk membantu mencegah pencemaran sumber air yang ada di sekitarnya. Memanfaatkan jamban keluarga yang bersih dan sehat juga tidak mengundang datangnya lalat atau serangga yang dapat menjadi penular penyakit yang dapat diakibatkan oleh tinja manusia, seperti diare, kolera, disentri, typus, kecacingan, berbagai penyakit saluran pencernaan, macam-macam penyakit kulit dan keracunan. Jamban yang tidak saniter menjadi sumber penyebaran Ecoli, dan bakteri penyebab diare (Depkes RI, 2006).

\section{Kesimpulan}

Kesimpulan penelitian ini yaitu diperoleh variabel yang memiliki faktor risiko diantaranya tingkat pengetahuan ibu (OR: 16), riwayat pemberian ASI (OR: 28,5), kebiasaan ibu mencuci tangan (OR: 16), jenis jamban (OR: 9,33), dan kepadatan lalat (OR: $9,33)$.

\section{Daftar Pustaka}

Direktorat Jendral Pengendalian Penyakit dan Penyehatan Lingkungan Kementerian Kesehatan Republik Indonesia. (2005). Shigellosis. Jakarta: Direktorat Jendral Pengendalian Penyakit dan Penyehatan Lingkungan Kementerian Kesehatan Republik Indonesia.

Badan Perencanaan Pembangunan Nasional. Peta Jalan SDGs Indonesia. (2020).

Hernayanti MR, Wahyuning HP. (2019). FaktorFaktor yang Berhubungan dengan Kejadian Diare pada Anak Usia 6-24 Bulan di Wilayah Kerja Puskesmas Sewon 1 Kabupaten Bantul

Kemenkes RI. (2018). Profil Kesehatan Tahun 2017. Jakarta: Kementrian Kesehatan RI.

Kemenkes RI. (2019). Hasil Utama Riset Kesehatan Dasar Tahun 2018. Jakarta: Lembaga Penerbit Badan Penelitian dan Pengembangan Kesehatan

Oliveira RKL de, Oliveira BSB de, Bezerra JC, Silva MJN da, Sousa Melo FM de, Joventino ES. (2017). Influence of socio-economic conditions and maternal knowledge in selfeffectiveness for prevention of childhood diarrhea. Escola Anna Nery. 21(4):e20160361.

Partawihardja, S. (1991). Pengantar Diare Akut Anak Diare kronik Anak Suatu Pengenalan Awal Penatalaksanaan Dietetik Penderita Diare AnakBadan Penerbit Universitas Diponogoro. Semarang.
Departemen Kesehatan RI. (2005). Laporan Hasil Riset Kesehatan Dasar (RISKESDA) Nasional 2007. Badan Penelitian dan Pengembangan Kesehatan Depkes RI. Jakarta 2008

Sander, M. A. (2005). Hubungan Faktor Sosio Budaya dengan Kejadian Diare di desa Candinegoro Kecamatan Wonoayu Sidoarjo. Jurnal Medika. Vol. 2. No. 2. Juli-Desember 2005: 163-193.

Departemen Kesehatan. Pedoman Pemberantasan Penyakit Diare. Jakarta: Ditjen PPM dan PL. (2005)

Lever DS, Soffer E. (2009). Acute Diarrhea. Cleveland Clinic Center for Continuing Education. Philadelphia.

Kementrian Kesehatan RI. (2011). Situasi Diare di Indonesia. Buletin Jendela Data dan Informasi Kesehatan

Yulianto Wijaya. (2012). Faktor Risiko Kejadian Diare Balita Di Sekitar TPS Banaran Kampus Unnes. Unnes Journal of Public Health.

Lailatul Mafazah. (2013). Ketersediaan Sarana Sanitasi Dasar, Personal Hygiene Ibu dan Kejadian Diare. Unnes Journal of Public Health

Laila Kamilla, Suhartono, Nur Endah W. (2018). Hubungan Praktek Personal Hygiene Ibu dan Kondisi Sanitasi Lingkungan Rumah dengan 
Kejadian Diare pada Balita di Puskesmas Kampung Dalam Kecamatan Pontianak Timur. Jurnal

Kesehatan Lingkungan Indonesia, Universitas Diponegoro.

Hannif, Nenny Sri Mulyani, Susy Kuscithawati. (2011). Faktor Risiko Diare Akut pada Balita. Berita Kedokteran Masyarakat, Universitas Gadjah Mada.

Susi Hartati, Nurazila. (2018). Faktor yang Mempengaruhi Kejadian Diare pada Balita di Wilayah Kerja Puskesmas Rejosari Pekanbaru. Jurnal Endurance: Kajial Ilmiah Problema Kesehatan, LLDIKTI Wilayah X.

Herry Tomy Ferllando, Supriyono Aswafi. (2015). Hubungan antara Sanitasi Lingkungan dan Personal Hygiene Ibu dengan Kejadian Diare pada Balita di Wilayah Kerja Puskesmas Mangkang. Visikes: Jurnal Kesehatan Masyarakat, Universitas Dian Nus wantoro.

WHO. (2009). Diarrhoeal disease. Juli 2014.

Tietjen L. (2004). Panduan Pencegahan Infeksi. Jakarta: Yayasan Bina Pustaka Sarwono Prawirohardjo.
Sugianto. (1983). Penyediaan Air Bersih Bagi Masyarakat. Sekolah Kesehatan.

Ngaw S. (2011). Hubungan Pengetahuan dan Perilaku Hidup Bersih dan Sehat (PHBS) dengan Kejadian Diare pada Balita.

Kementerian Kesehatan RI. (2013). Riset kesehatan dasar.

Departemen Kesehatan RI. (2006). Kumpulan modul kursus hygiene sanitasi makanan dan minuman. Sub Direktorat Sanitasi Makanan dan Bahan Pangan Direktorat Penyehatan Lingkungan. Jakarta: Ditjen PPM dan PL.

Winda Wijayanti (2010). Hubungan Antara Pemberian ASI Eksklusif dengan Angka Kejadian Diare pada Bayi Umur 0-6 Bulan di Puskesmas Gilingan Kecamatan Banjarsari Surakarta. UNS Institutional Respiratory (UNS-IR).

Depkes RI. (2011). Situasi Diare Di Indonesia. Jakart : Depkes RI. 